Miscellanea Anthropologica et Sociologica 2019, 20(1): 196-209

Magdalena Hoły-Łuczaj ${ }^{1}$

\title{
On the Absence of Eco-phenomenology in Poland
}

The paper aims to identify and explain the absence of eco-phenomenological perspective in Polish philosophy. Eco-phenomenology, which emerged as the specialized area of phenomenological movement in the 1980s, explores relations between human beings and nature. The lack of it in Poland, as the paper argues, is not only due to the specific political situation, but primarily because of the great impact of Jozef Tischner's "philosophy of drama," which has strongly anthropocentric implications.

Key words: eco-phenomenology, environmental ethics, Polish philosophy, Tischner, philosophy of drama

\section{Introduction}

Eco-phenomenology is one of the most interesting crossroads of ontology and ethics in contemporary philosophy. This branch of phenomenology is not limited to the analysis of relations between human beings on which traditional ethics is focused, but explores interrelations between humans and environment. The field of eco-phenomenology is growing fast and gets more and more attention. In Poland, however, eco-phenomenology is barely known and does not have any representatives. In the article, I shall explain reasons for this absence. I will argue that this is mainly due to the great influence of Jozef Tischner's philosophy of drama, which was equally original and anthropocentric theory.

The structure of the paper is as follows. In the first part, I outline basic principles of eco-phenomenology. Next, I reconstruct the development of environmental philosophy in Poland. In the third, main, part, I analyze and discuss Tischner's concepts related to the nonhuman beings and the environment. In the fourth part, I unpack this intellectual heritage in works of Tischner's students.

1 University of Information Technology and Management in Rzeszow, Department of Philosophy and Cognitive Sciences; mholy@wsiz.rzeszow.pl. 


\section{Ecology and Phenomenological Perspective}

The environmental philosophy claims it can bring a change to the world and transform current, ecologically destructive attitude toward the environment into respectful and caring, by altering thinking about the identity of human beings, nature, and their mutual relations. That is to say, environmental philosophy believes our behavior and disposition towards others is determined by the recognition of how someone sees his or her own position and the position of other beings. Such a perspective seems to be phenomenological par excellence (see Kirkman 2002: 79). And eco-phenomenology makes an intensive use of it.

Phenomenology has a reputation as a highly abstract, theoretical inquiry into consciousness, being, or structure of objects (Toadvine 2003: 10). While it seems that this is a well-deserved reputation, we should remember that phenomenology is internally very diverse. Some phenomenologists put emphasis that they do purely theoretical work, whereas others point to the practical implications of the phenomenological investigations. This is the case of eco-phenomenology. Representatives of it are aware that world faces serious environmental concerns and they want to help solve practical problems related to it by careful philosophical examination. They believe that contribution, which philosophy can offer, is an insightful clarification of our metaphysical and ethical assumptions, which underlie all of our current behavior. To be precise, they claim it is phenomenology alone that can alter presuppositions which guide and influence our behavior.

It is so - as Ted Toadvine, one of the most prominent representatives of ecophenomenology, holds - because phenomenology takes its starting point in return to things, that it is the world as we experience - perceive, recognize, value - it. This perspective undermines the distinction between theory and practice. According to it, the way we see the world (domain of theory) determines the way we act (domain of practice). This concerns also human attitude toward nature, the heart of the matter for eco-phenomenology.

The first works which employed ecophenomenological perspective were written in the 1980s when environmental philosophy has already been well established. But it was in 2001 when the most important book on ecophenomenology was published. It was entitled just Ecophenomenology. More interesting was a subtitle of this seminal book: Back to the Earth Itself. It gives us, as Iain Thomson puts it, a clever twist on the famous battle-cry of Husserlian phenomenology - 'Back to the things themselves!' ( $Z u$ den Sachen selbst!) - in which the crucial Sache, the 'heart of the matter' or 'sake', has been replaced by 'earth' (Thomson 2004: 386). It is the earth and our relation with it, which we need to rethink in order to find some remedy for the contemporary environmental crisis. 
Eco-phenomenology, which emerges at the crossroad of ethics and ontology, is a kind of philosophical anthropology. It asks about human place in the order of reality, primarily concentrating on the relations between nature and human beings. The idea inspiring the eco-phenomenological movement is that today we have incorrect presuppositions about it. This is the ballast of tradition which weighs us down. According to eco-phenomenology, the most environmentallydestructive ethical and metaphysical concepts inherited from the past centuries are dualisms of mind and world, man and nature, and matter and spirit. They result in the image of human being as a superior being which can and should dominate and arbitrarily use the rest of the world, according to our, human, needs (Toadvine 2003: 10-12).

Eco-phenomenology advocates reorientation of human relation to the (natural) world by providing alternative ontological categories. They are indivisibility of man and world, the interrelatedness of them, and the possibility to uncover the identity of nonhuman beings, which is different from creating it. Eco-phenomenologists believe that such assumptions are adequate for describing the fundamentals of reality. Supporters of the eco-phenomenology movement argue that conceptual dichotomies (typical for Platonism and Cartesianism) fundamentally mischaracterize our ordinary experience. Eco-phenomenology, according to them, offers a perspective, which is far from the counterintuitive assumption inherited from the history of philosophy (Toadvine 2003: 12-14).

Here, however, we should specify that eco-phenomenologists do not condemn the entire history of philosophy. They criticize mainly some ancient and modern concepts, already mentioned Platonism and Cartesianism alone. The heroes, or speaking in a more moderate manner, predecessors of ecophenomenology are Freidrich Nietzsche and the most important phenomenologists: Edmund Husserl, Martin Heidegger, Maurice Merleau-Ponty, and Emmanuel Levinas. What needs to be underlined is that their ideas according to eco-phenomenology are not incomplete and require further development but constitute a powerful source of inspiration. In this sense, the relationships of authors in question with ecophenomenology are only indirect - they are implied (but in a valid manner) to them by the supporters of eco-phenomenology. Below is provided, due to obvious space limits, a brief overview of the their key concepts from the standpoint of ecophenomenology.

Husserl is a relevant thinker for eco-phenomenology as the founder of phenomology, who formulated its basic principles, according to which our perception of what we call 'reality' is complex phenomenon, grounded in both our subjectivity and external elements. Husserl also layed down foundations for a new approach to nature and culture since it offers a description of reality as value-laden and meaning-structured lifeworld. Furthermore, his critique of naturalism helps 
to overcome uncritical scientism and instrumental rationality (Toadvine 2016, 2003; Brown 2003; Kohak 2003). And last, but not least, he established the phenomenological movement to which belong key figures of the twentieth century continental philosophy.

Heidegger seems to be the most significant figure among them. It was his concept of being-in-the-world from early writings and critique of technology as well as the idea of "letting be" from the later works, which influenced so strongly environmental philosophy and eco-phenomenology (Toadvine 2016, 2003; Zimmerman 1990). But even though over the past decades environmentalists have consistently focused more on Heidegger than on any other philosopher, we cannot forget that two French philosophers - Merleau-Ponty and Levinas - also provided a great source of inspiration for eco-phenomenology. In Merleau-Ponty, these are primarily descriptions of corporeality and the flesh of the world concept of phenomenology as "concrete reflection" (Langer 2003). He shows that bodily, that is natural, element is an irreducible part of human condition, what can be seen as a recognition of kinship with nature. Levinas, on the other hand, helps to think the otherness of nonhuman beings which deserves respect and care and requires abandoning hubristic attitude towards the environment by human beings (Edelglass et al. 2012; Calarco 2010).

All of the above figures are well-known philosophers in Poland, whose ideas are often analyzed jointly in works on anthropological or ethical issues. Yet, there are never or hardly ever read in Poland as pro-environmental thinkers. ${ }^{2}$ In what follows, I shall reflect on the reasons for this absence.

\section{Environmental Philosophy in Poland}

Let me begin with describing problematic situation of the development of environmental philosophy, or more broadly speaking environmental thinking in Poland. It can be best illustrated with some anecdote. At the turn of the 1970s and the 1980s, during the visit in West Germany, a member of Polish anticommunist organization, who attempted to present it as a left-wing group, was asked by some German activist: "and what about your green policy? what are your environmental actions?". Dead silence answered him. Both parties were equally shocked. German activist couldn't understand how left-wing organization can omit issues related to the environment protection, while Polish couldn't understand that someone would expect interest in green issues from people who had to struggle with the persecution of the anti-regime opposition, lack of the free speech, and poverty caused by the bad economy.

2 The following works are rare exceptions: Bialer 2015; Fiut 2005; Przyłębski 1992. 
So, as Dominika Dzwonkowska reminds us, while Rachel Carson was awaking a pro-environmental awareness in the 1960s in the USA, in Poland the area of ecological problems was not even discussed. In Poland, as in the other countries behind the Iron Curtain, the destruction of nature was of minimal concern. The Polish government was focused on industrialization and the priority was how to produce more steel and not how to protect the environment (Dzwonkowska 2017: 136).

In Poland problems typical for environmental ethics become a subject of interest at the turn of the 1980s and the 1990s. Back then first works introducing basic concepts of environmental philosophy for Polish audience were published. They analyzed and discussed Thomas Regan's idea of moral extensionism, Robin Attfield's individualistic environmental ethics, Paul W. Taylor's ethics of respect for nature, the land ethic of Aldo Leopold and J. Baird Callicott, deep ecology, Holmes Rolston III ecocentrism, Gaia hypothesis (Tyburski 2006: 12-14). These books have given the impulse for others to carry out research in environmental ethics and have started the intellectual debate within this field in Poland (Dzwonkowska 2017: 138). At the turn of the 1990s and the 2000s Polish scholars started to develop their own ideas. Today, there is a wide array of concepts offered by them.

One of the most clear-cut is Christian environmental ethics (Jozef M. Dolega, T. Slipko, G. Holub). This approach is an anthropocentric one. It is grounded in the classical idea of the ladder of beings, according to which human beings rule over nature. Yet, Christian environmental ethics points to the fact that it shouldn't be cruel exploitation, which does not consider any constraints of this use. Human beings have to take care of nature in order avoid an ecological crisis, which effects would be harmful to all mankind. Another premise of this approach is that nature is the gift given by God, who made human beings responsible for it (Dzwonkowska 2017: 144-145).

Another distinct approach is scientific biocentrism of Zdzislawa Piątek. According to her, the theory of evolution is a test of the neutral perception of living Nature. It rejects the illusion of anthropocentrism and it overcomes the tendency to accept teleological explanations. So, for Piatek, unlike Paul Taylor, living organisms are not teleological centers of life. However, Piatek recognizes Taylor's philosophy as the most appropriate in terms of enabling human beings to live with the other organisms on Earth in harmony (Piątek 2008, 1998; Dzwonkowska 2017: 140).

Definitely worth mentioning is also Wlodzimierz Tyburski's environmental axiology. He constructed the catalogue of environmental values. Basically, it consists of two groups: (1) values that are the aims themselves: life and health and (2) values that are means to achieve some goal: responsibility, moderation, justice, solidarity/community. Such a formulation of set of environmental reveals its close connection to biocentrism, according to which undisturbed life and well-being of 
some entity is a core good, and all actions that contribute to maintain it are also positively assessed (Dzwonkowska 2017: 141-142).

Finally, we should point to Henryk Skolimowski's eco-philosophy. He also defined the set of pro-environmental values grounded in the claim that "the world is a sanctuary". The values for the new ethics are: reverence for life; responsibility for the environment; sympathy/compassion; moderation/temperance; diversity (Dzwonkowska 2017: 143; Małecka, Stark 2018). Skolimowski is best known Polish environmental philosopher, but we should keep in mind that for decades he worked and taught abroad, mainly in United Kingdom and the United States.

The other interesting ideas in the field of environmental ethics were brought by Andrzej Papuzinski, Zbigniew Hull, Helena Ciazela, Ignacy Stanislaw Fiut, just to name a few, who pointed to various aspects of ecological issues.

So even though environmental philosophy is not so popular in Poland as it is in the United States, Canada, Scandinavian countries, Netherlands or Germany, there is quite a big number of various approaches to it with the different theoretical background. Yet, we will not find eco-phenomenology among them. Why? My hypothesis is that to a large extent it is due to the impact of Josef Tischner philosophy of drama - one of the most original theories in the history of Polish philosophy.

\section{Development of Phenomenology in Poland}

In Poland, the father of phenomenology is Roman Ingarden (1893-1970), a direct student of Edmund Husserl. He was a versatile philosopher, who worked in the field of ontology (he opposed the idealism of his teacher), epistemology, aesthetics, ethics, and anthropology. However, we need to bear in mind that it was ontology which was the most important field of research for Ingarden. All his other ideas - epistemological, ethical, anthropological - are grounded in his ontology. That is to say, Ingarden's anthropology is complementary to his ontological concepts, yet the latter are the core, when it comes to the significance and volume of his work. Having said that, we cannot forget how important is his Ksiażeczka o człowieku ("Little Book About Man"), in which Ingarden develops, among other concepts, his interesting and original theory of responsibility. Of particular importance for us is that there could be traced some implications for environmental ethics in it (for example a distinction between moral agency and patiency of animals - see Ingarden 1973: 82, 116-117). They are not explicit (Ingarden died when environmental philosophy was just emerging), but they could be treated as a source of inspiration, as it is in the case of Heidegger or Levinas. Yet, they have never been examined from this angle. As it was already indicated, I believe this is a result of Tischner's influence on Polish phenomenology. 
Józef Tischner (1931-2000) was both a priest and a philosopher, who unlike the great majority of Christian or Catholic theorist preferred phenomenology - as Ingarden's student - to Thomistic approach. Tischner attended the seminar conducted by Ingarden, who was later a supervisor of his master (1959) and doctoral thesis (1963) at Jagiellonian University in Cracow. Since the 1970s Tischner was gaining more and more popularity. He has influenced subsequent generations of philosophers in Poland. Today, there is The Tischner Institute, which takes care of Tischner's legacy and promotes his works. Each year 'Tischner Days' take place in Cracow in order to celebrate the memory of him and present further perspectives of research in his philosophy. ${ }^{3}$

Tischner made the most significant contribution in the field of phenomenological ethics and anthropology in Poland (see Wolenski and Skoczynski 2010: 543). He was one of the first commentators of the philosophy of Martin Heidegger and Emmanuel Levinas in Poland. He introduced their ideas to a wider philosophical audience. His well-known book Myślenie wedtug wartości (Thinking in Accordance with Values, 1982) is a collection of texts, which the core part discusses concepts brought by Husserl and philosophers belonging to his circle: Heidegger, Ingarden, Gadamer, and Levinas. Some of them were written already in 1976. Tischner, however, was not only an interpreter of those great thinkers, but he also has created his own theory drawing upon their ideas. Another, equally important source of inspiration for him was the philosophy of dialogue represented by Martin Buber. ${ }^{4}$ From the combination of different elements of Heidegger's phenomenology (i.e. temporality, conscience), Levinas philosophy (i.e. otherness, face), and Buber's paradigm of I-Though relation emerged his original "philosophy of drama".

\section{Tischner's Philosophy of Drama}

A book with such a title (Filozofia dramatu. Wprowadzenie - "The Philosophy of Drama. Introduction") was published in 1990. The framework of the philosophy of drama is the idea that the relations between human beings can be described and analyzed as a peculiar kind of drama, or theatrical performance.

The most fundamental in it is what is happening between people - "the actors". Their relations is the actual action of the drama. The essential of it is the openness to another human being which can never be objectified. It is different with "the

See: http://www.tischner.org.pl/eng (access: 24.04.2019).

4 Interestingly, Martin Buber is also very important figure for environmental philosophy, what was discussed also in Poland: see Bialer 2015; Grochowska 2008. 
scene", which for Tischner was the rest of the world - that is to say, all other nonhuman beings.

In Polish one can say that something is either "in" the world or "at" the world to localize or describe the most general place, where human beings and things can be. The second expression is even more popular. Tischner referred to it in recognizing that humans are of the world as the actors are at the stage. What is important for the matter of our discussion, the author of The Philosophy of Dra$m a$ argued that the relation between two actors is completely different than between actors and the scene. Human beings are always agents or subjects. Tischner claimed that we always should see in the other human being a subject, whose subjectivity should never be pressed into ready categories and assumptions or adjusted to our expectations, imaginations, and projections. We should always "be open dialogically" toward other human beings (Tischner 2001: 9). That is to say, we should be ready to let the other person freely disclose herself or himself in their otherness, uniqueness, and peculiarity. Nonhuman beings, on the other hand, have to be always objects for us - we have to fit them into our mental and pragmatic typologies so that they become understandable and tamed (Tischner 2001: 13). According to Tischner objectifying is the only way humans can experience what they find in their surroundings.

This is a strongly dualistic concept. Tischner believed that nonhuman beings and human beings are "the opposite": "[Subject] is the opposite to object - nothing more and nothing less" (Tischner 2001: 13). This definition (a little vaque and not clear cut to say the least) tells us that nonhuman beings are completely disparate to human beings. Yet, they are not only different but also inferior according to philosophy of drama. Tischner believed that the world, "the scene", is something that is below us both descriptively and prescriptively. The statement "Under our feet is our world - the scene of the drama" ${ }^{\prime 5}$ is commented as follows:

The scene is at the feet of a man. The Bible says: subdue the earth. A human being subordinate everything, what is - in accordance with nature - below [Tischner highlights this word - MHL] him. The basic act of subordination is objectification. ${ }^{6}$

\section{And further:}

After the creation of the first people, God said: subdue the Earth. These words are still in us. They determine the most original relation of human being to the scene. First of all, they show the place of the earth in the hierarchy of values: man

\footnotetext{
5 "Pod naszymi stopami jest nasz świat - scena dramatu” (Tischner 2001: 8).

6 "Scena znajduje się u stóp człowieka. Mówi Pismo: czyńcie sobie ziemię poddaną. Człowiek poddaje sobie to, co wedle natury znajduje się niżej człowieka. Aktem podstawowym poddania jest akt uprzedmiotowienia" (Tischner 2001: 9).
} 
is above the earth and the earth below man. Earth is not a God. Earth is not a human being. ${ }^{7}$

The anthropocentric conviction that the scene - a totality of nonhuman beings - is situated lower than human beings is supported by the quote from the Bible (we shouldn't forget that Tischner was a priest): "subdue the earth". This famous saying is usually interpreted on the ground of environmental philosophy and beyond as an encouragement for people to exploit nature (see Lovejoy 2009: 131). Even though some scholars (as for example already mentioned advocates of Christian environmental philosophy) seek to mitigate such a reading, arguing that it doesn't mean that human beings are allowed to predatory abusage or plundering nature, these words cannot be understood otherwise than showing that satisfying human interests is the ultimate and the only goal of the whole universe. This is also the case of Tischner's philosophy of drama.

However, we have to remember that Tischner primarily didn't aim to diminish the status of nature, but rather attempted to enhance the status of human beings, showing how valuable they are and how much they deserve. We cannot lose sight of the overall context of his philosophy. Tischner intended to reinforce the condition of human being as an individual because he believed (and was right in it) that in the $20^{\text {th }}$ century human beings were too often treated as a kind of a mass. That century was cruelly marked by two totalitarianism. Human individuality was disrespected - it served only "greater" good: race or state. Tischner's phenomenology was driven by the desire to ground inherent value of each human beings, which we always meet face to face (in Levinasian sense). If nonhuman beings drew his attention they were always a kind of background or the scene of human existence. The point of reference was always human beings. Such an approach was already presented in Etyka Solidarności (The Ethics of Solidarity, 1981). He describes here a home during tough times in Polish history as follows:

Home became a refuge, in which peasant could protect his identity. Whoever abandoned the farm, has made betrayal. But we do not betray stones, do not betray the trees themselves, do not betray the soil as such. When someone betrayed, he betrayed someone - a man. Stones, trees, soil, and everything that the farm constituted of was one great indication of the people who we must always be faithful. ${ }^{8}$

\footnotetext{
7 "Po stworzeniu pierwszych ludzi Bóg rzekł: «czyńcie sobie ziemię poddaną». Słowa te są nadal w nas. Określają podstawowy zarys stosunku człowieka do sceny dramatu. Przede wszystkim ukazują miejsce ziemi w hierarchii wartości: człowiek jest ponad ziemią, a ziemia poniżej człowieka. Ziemia nie jest bogiem. Ziemia nie jest człowiekiem” (Tischner 2005: 80).

8 "Dom stawał się «placówką», w której chłop bronił swojej tożsamości. Kto porzucał gospodarstwo, ten zdradzał. Ale przecież nie zdradza się kamieni, nie zdradza się samych drzew, nie zdradza się gleby jako takiej. Gdy ktoś zdradza, zdradza kogoś - człowieka. Kamienie, drzewa, gleba,
} 
The problem with Tischner's approach, however, is not that he looked at reality through the prism of human beings' affairs and was more interested in them than nonhuman beings. The most bothering issue is that hat he sought to reinforce it at the cost of nature. Such passages reveal strongly anthropocentric character of Tischner's philosophy, if we refer to the distinction between strong and weak anthropocentrism. The latter holds that mediation in human interests is irreducible component in our perception of the reality, but ascribe at least some noninstrumental value to nonhuman beings (Hargrove 2006: 186). Tischner's claims, whereas, are oriented purely to human well-being - nonhuman beings are merely tools (instruments) to gain it. In The Philosophy of Drama we read:

Anyone who neglects nature can cause a scene rebellion. The wisdom pervading farming says how should deal with nature. It tells the farmer what he has to do in order to bring out of nature what is best, that is what serves life best. Various forms of life are arranged in a hierarchy. Therefore, the wisdom of farming must think hierarchically. Human life is more valuable than the life of grass, tree life, animal life. Man is at [in] the world, the world-scene is below [Tischner again highlights this word - MHL]. ${ }^{9}$

This passage starts with the assumption that people must not overexploit nature, but should rather proceed in accordance with natural constraints. However, the justification for this claim is instrumental - Tischner argues that we need to act this way if we want to get out of nature what serves life best. Moreover, he doesn't refer here to the common meaning of life in the environmental philosophy (basically, the totality of nature), but only that of human beings, what he explicitly says elsewhere: "The earth serves human beings only when human beings know how to serve the Earth. Human beings need to help the Earth to breed more and better to sustain their lives". ${ }^{10}$

Tischner advanced the claim that there is the objective hierarchy of universe, symbolized by the figure of the great chain of being, which was criticized on the ground of environmental philosophy. Obviously, not every environmental philosopher is an egalitarianist, but the critique of the great chain of being was common

I wszystko, co stanowiło gospodarstwo, było jednym, wielkim wskazaniem na ludzi, którym zawsze trzeba być wiernym" (Tischner 2005: 82).

9 "Kto zlekceważy naturę, może spowodować bunt sceny. O tym, jak należy postępować z naturą, mówi mądrość przenikająca gospodarowanie. Ukazuje ona gospodarzowi, co powinien zrobić, by wydobyć z natury to, co najlepsze, czyli to, co najlepiej służy życiu. Rozmaite formy życia układają się w hierarchię. Dlatego mądrość gospodarowania musi myśleć hierarchicznie. Życie człowieka jest cenniejsze od życia trawy, życia drzewa, życia zwierząt. Człowiek jest bowiem na świecie, świat-scena jest poniżej [Tischner again highlights this word - MHL] człowieka (Tischner 2001: 221).

10 "Ziemia służy człowiekowi tylko wtedy, gdy człowiek potrafi jej służyć. Człowiek musi pomóc ziemi, aby rodziła lepiej i więcej, by w ten sposób podtrzymywała jego życie" (Tischner 2005: 83). 
since it gives too easily alibi for the abusage of nature (Lovejoy 2009: 128-131; Sessions 1995: 159-160). This concept supports the conviction that human beings have every right - as "superior" beings - not only to satisfy their needs but also secondary interests or even whims. It does not leave room for own good of nonhuman beings. Everything is subordinated to human beings. Tischner's theory rests on this assumption. He does not suggest to stop the exploitation of nature because of its own sake, but because it could disturb sustaining the life of human beings. People should protect nature, but only due to the fact its devastation might have harmful effects for themselves. Tischner advocates care for nature, yet it is anthropocentric and instrumental reinforcement, which does not allow to see in nature a partner, but only a servant.

Summing up, Tischner's anthropocentrism, which is clearly visible, should be primarily understood as the opposite to Marxist, or more precisely, communist state-centrism. According to him, each human role is always oriented directly toward other human beings and not the development of economy (e.g. "farming is the role of a human being [recieved] from other human beings for other human beings" - Tischner 2005: 84). Unfortunately, the connotations of such claims, as well as some of his other direct statements, diminished the ontological status of nature, and in result its ethical status. Tischner phenomenology was occupied with the problems of freedom, responsibility, wrongdoing, evil as belonging exclusively to the domain of human interrelations.

\section{Tischner's Followers}

This approach was taken over by other Polish phenomenologically oriented ethicists or theorists working in the field of philosophical anthropology. The most prominent representatives of phenomenological tradition in ethics or philosophical anthropology in Poland were fellow-workers or students of Tischner. We can list here, among others: Karol Tarnowski (1937-), Jacek Filek (1945-), Tadeusz Gadacz (1955-), and Cezary Wodziński (1959-2016). All of them investigate further issues essential for Tischner's philosophy work. They analyzed problems of freedom and responsibility (Gadacz, Filek), subject (Tarnowski), evil (Wodziński) referring to primarily Husserl, Heidegger, Levinas, and Buber. Even though neither of them employs specific categories and terminology of the philosophy of drama, their works represent the same attitude toward the scope of moral consideration: they believe it is purely human sphere. Natural, nonhuman beings are excluded from the domain of ethics. In their writings, there are no signals of non-anthropocentric turn.

It can be illustrated with two recent publications, respectively on Tischner's philosophy and ethics. First one is a book by Dobrosław Kot entitled Myślenie 
dramatyczne ("Dramatic Thinking", 2016). It aims to examine the problem of thinking as a fundamental activity for human beings and at the same time, it's the newest study on Tischner's philosophy of drama (Kot 2016: 9-13). Kot highlights that Tischner's work is of crucial importance for him but he seeks to critically refer to it (Kot 2016: 13). However, when it comes to the idea of the scene, Kot does not make any critical remarks. He accepts recognizing the world as the scene (Kot 2016: 42,44), with which relations are radically different from relations with other human beings (Kot 2016: 87, 160).

Even more telling is another example, which is Jacek Filek's book Etyka. Reinterpretacja (Ethics. Reinterpretation, 2014). Filek reconstructs the development of ethics, claiming that there were basically three stages of it. In the first period (Socrates-Augustine), ethics was focused on the issue of truth. During the second period (Descartes-Nietzsche) the most important was a problem of freedom. In the third period (Husserl-Levinas) the question of responsibility came to the fore. Filek's work is without a doubt an interesting, in-depth novel mapping of ethics. The only drawback is that it limits the scope of ethics to human beings with any discussion. Such boundaries of ethics are accepted by Filek as obvious. What is particularly striking about it is that even Albert Schweitzer's philosophy is presented without its environmental implications. Schweitzer's concept of "reverence for life", which sense is best expressed in famous quotation "I am life which wills to live, and I exist in the midst of life which wills to live", was a great source for environmental philosophy since it supports belief that not only human beings, but also other living things deserve respect and care. Filek, however, reads this famous saying only as a call for respect for life, which everyone (that is every human being) internally experiences and not abstract notions of the "person" or the "moral law" (Filek 2014: 206). Filek does it even though he knew "environmental" interpretations of Schweitzer as the reviewer for Piatek's book (1998).

This is not to say that Heidegger's or Levinas' philosophy are obviously nonanthropocentric and can be read as environmentally oriented without any obstacles. Such interpretations are accompanied by many controversies. ${ }^{11}$ Debate on this subject, however, is intense, inspiring, and definitely worth following. Unfortunately, Polish phenomenology seems to ignore it.

\section{Conclusion}

Eco-phenomenology offers a new paradigm of relations between human beings and the environment, which is supposed to overturn dominating, arrogantly anthropocentric approach to nature. Eco-phenomenology goes beyond simple

11 See Löwith 1971; Jonas 1994; Tonner 2011. 
division of ethics and metaphysics because argues that ethos should be grounded in the most fundamental localization of human being, which is his or her place on the metaphysical plane.

In Poland, even though the field of environmental philosophy is intensively growing, this movement does not have any phenomenological inspirations. I sought to show it might be due to the impact of Jozef Tischner's philosophy. He is undoubtedly one of the most significant contemporary Polish philosophers. He was one of the first to introduce Heidegger's and Levinas' philosophy to Polish philosophical audience and he has strongly influenced their reception in Poland. His interpretation of their phenomenological concepts, as well as his own philosophy of drama, which he drew upon them, presented human individuals not only as absolutely intrinsically valuable but also as superior to all other creatures in the world. Even though he aimed in the first place to enhance the status of human beings, which he believed to be undervalued in the contemporary world, it suggested largely anthropocentric worldview criticized by environmental philosophy in general, and eco-phenomenology in particular. This, I think, has hindered the adoption of eco-phenomenological perspective by Polish phenomenology, even though Roman Ingarden's concepts can have implications for environmental ethics. I believe it would be worth re-examining them through the prism of ecophenomenology, as well as include this perspective in ongoing phenomenological research in Poland, expanding its horizons in metaphysics and ethics.

Bibliography

Bialer O., 2015, Husserl's Phenomenological Heritage as a Source Of Innovative Inspiration and Critical Evaluation for Emmanuel Levinas' Ethics and Martin Buber's Ecophenomenology, Dialogue and Universalism, vol. 25(3), pp. 127-139.

Calarco M., 2010, Faced by Animals [in:] P. Atterton Pete, M. Calarco (eds.), Radicalizing Levinas, Albany: State University of New Yok Press.

Dzwonkowska D., 2017, Environmental Ethics in Poland, Journal of Agricultural and Environmental Ethics, vol. 30(1), pp. 135-151.

Edelglass W., Hatley J., Diehm C. (eds.), 2012, Facing Nature: Levinas and Environmental Thought, Pittsburgh: Duquesne University Press.

Filek J., 2014, Etyka. Reinterpretacja, Tyniec: Homini.

Fiut I.S., 2005, Jak byłaby możliwa ekofenomenologia? [in:] P. Czarnecki (ed.), Filozofia bliższa życiu: księga pamiątkowa ofiarowana profesorowi Wojciechowi Słomskiemu, vol. 1, Warszawa: WSFiZ.

Grochowska I., 2008, Filozofia dialogu jako jeden z aspektów zrównoważonego rozwoju, Problemy ekorozwoju - Problems of Sustainable Development, vol. 3(1), pp. 67-72.

Ingarden R., 1973, Książeczka o człowieku, Kraków: Wydawnictwo Literackie Kraków.

Jonas H., 1999, Religia gnozy, transl. M. Klimowicz, Kraków: Platan.

Kot D., 2016, Myślenie dramatyczne, Kraków: Copernicus Center Press. 
Langer M., Nietzsche, Heidegger, and Merleau-Ponty: Some of their Contributions and Limitations for Environmentalism [in:] Ch. Brown, T. Toadvine (eds.), Eco-phenomenology. Back to the Earth itself, Albany: State University of New Yok Press.

Lovejoy A.O., 2009, Wielki łańcuch bytu. Studium historii pewnej idei, transl. A. Przybysławski, Gdańsk: Słowo/obraz terytoria.

Löwith K., 1971, Zu Heideggers Seinsfrage: Die Nature des Menschen und die Welt der Natur [in:] K. Löwith, Aufsatze und Vorträge, 1930-1970, Stuttgart: Kohlhammer Verlag.

Małecka A., Stark K., 2018, Henryk Skolimowski's Eco-Philosophy as a Project of Living Philosophy [in:] W. Smith, J. Smith, D. Verducci (eds.), Eco-Phenomenology: Life, Human Life, Post-Human Life in the Harmony of the Cosmos. Analecta Husserliana (The Yearbook of Phenomenological Research), vol. CXXI, Cham: Springer.

Piątek Z., 1998, Etyka środowiskowa. Nowe spojrzenie na miejsce człowieka $w$ przyrodzie, Kraków: Księgarnia Akademicka.

Piątek Z., 2008, Ekofilozofia, Kraków: Wydawnictwo UJ.

Przyłębski A., 1992, M. Heidegger a tzw. ekologia głęboka [in:] B. Andrzejewski (ed.), Ochrona środowiska w refleksji humanistycznej, Poznań: Wydawnictwo PTPN.

Sessions G., 1995, Ecocentrism and the Anthropocentric Detour [in:] G. Sessions (ed.), Deep Ecology for the twenty-first Century, Boston: Shambhala Publications.

Thomson I., 2004, Ontology and Ethics at the Intersection of Phenomenology and Environmental Philosophy, Inquiry, vol. 47(4), pp. 380-412.

Tischner J., 2001, Filozofia dramatu. Wprowadzenie, Kraków: SIW Znak.

Tischner J., 2005, Etyka Solidarności oraz Homo Sovieticus, Kraków: SIW Znak.

Toadvine T., 2003, Introduction [in:] C. Brown, T. Toadvine (eds.), Eco-phenomenology. Back to the Earth itself, Albany: State University of New Yok Press.

Toadvine T., 2016, Phenomenology and Environmental Ethics [in:] S.M. Gardiner \& A. Thompson (eds.), Oxford Handbook of Environmental Ethics, Oxford: Oxford University Press.

Tonner P., 2011, Are Animals poor in the World? A Critique of Heidegger's Anthropocentrism [in:] R. Boddice (ed.), Anthropocentrism. Humans, Animals, Environments, Leiden-Boston: Brill.

Tyburski W., 2006, Powstanie i rozwój filozofii ekologicznej, Problemy ekorozwoju - Problems of Sustainable Development, t. 1(1), pp. 7-15.

Woleński J., Skoczyński J., 2010, Historia filozofii polskiej, Kraków: WAM.

Zimmerman M.E., 1990, Heidegger's Confrontation with Modernity: Technology, Politics, and Art, Bloomington: Indiana University Press. 